\title{
IMPACT OF USAGE PROTECTED FATS ON THE SKIN AND HAIR OF SHAMI DOES FED ON HALOPHYTES UNDER DESERT CONDITIONS
}

\author{
Aisha S. Abdou ${ }^{1 *}$, Samia A. Hekal ${ }^{1}$, Naglaa S. Badawy ${ }^{1}$, Wael A. \\ Ramadan $^{1}$ and Salah Abo Bakr ${ }^{2}$ \\ ${ }^{1}$ Department of Wool Production and Technology, Desert Research \\ Center, El-Matareya, Cairo, Egypt \\ ${ }^{2}$ Department of Animal and Poultry Nutrition, Desert Research Center, \\ El-Matareya, Cairo, Egypt \\ *E-mail: aishaabdou12@yahoo.com
}

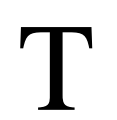

he influence of halophytic diets with or without inclusion with protected fats was studied on the hair follicle dimensions and activity in the skin of Shami goats. Fortytwo adult Shami goats were divided into three groups (14 each) fed on diets with a ratio of $40 \%$ concentrate and $60 \%$ roughage and drink fresh water twice daily. The roughage in the first group, which representing the control was berseem hay, while in the other two groups were a mixture of 50\% Atriplex halimus and Nummularia and $50 \%$ pearl millet with presence or absence of protected fats. Skin samples were taken to determine the hair follicle characteristics and activities. Results obtained indicated that feeding trails have small or no significant effects on the hair follicle dimensions or activities between tested and control groups and consequently elevated the negative effects of poor quality fibrous feed on follicle hair production and activity. A slight increase was found in the diameters of fibers from the secondary follicles in contrast with those of primary follicles, which showed a reversible trend. Meanwhile, the medulla thickness of the fibers produced from the primary follicles showed no significant changes corresponding to different feed trails. The histochemical evaluation revealed that significant differences in carbohydrate and protein contents of both primary and secondary follicle sheaths were found between the different treatment groups. The highest values of both carbohydrate and protein contents were recorded in the group which have protected fat in their diet. Animals fed on halophytes supplemented with protected fat were associated with higher sebaceous gland cell and nucleus diameters of both primary and secondary follicles. In an overall of conclusion, from the stand point of the skin follicle activity and hair production, the mixture of Atriplex halimus, Nummularia and pearl millet supplemented with protected fat could 
replace berseem hay. It is a promising feed resource in Sinai and newly reclaimed lands with similar environmental conditions.

Keywords: Shami goats, halophytes, protected fat, skin, histology, histochemistry

Goats in desert areas of Egypt are faced by overgrazed natural vegetation particularly those of the palatable species and the acute shortage of feed ingredients particularly during drought seasons. Some grasses and legumes have shown a great potential as fodders under saline and arid conditions in Sinai (El-Shaer, 1995). Halophytes represent the perennial forage shrubs in these regions, that are well adapted to salt and drought stresses. They can produce economically feasible biomass for grazing animals and provide low coat fodders for them (Girgis, 1994). Although, some halophytes could be accepted as forages utilized by sheep and goats, Aboul-Nasr (1998) and Craig et al. (1991) showed that many of these range plants have an adverse effect on animal health and containing chemical or physical factors that either limit or inhibit optimum animal performance.

As well as using fat supplements as a mean of raising the dietary energy density, it must also consider the need for specific fatty acids. The body requires specific amino acids and likewise requires specific fatty acids. Certain fatty acids have a positive effect on rumen efficiency (http://www.rwn.org.uk/rwn_cow_protected_fat.htm). However, with addition of protected fat in the diet, the supplementary fat does need to be protected in order to avoid impaired rumen function. Since skin is continuously exposed to internal and external influences that may alter its conditions and functioning. Modern nutritional science is devolving new insights into the relation between food intake and health and effects of food ingredients may improve to be biologically relevant for optimal skin condition (Boelsma et al., 2001).

In many developing countries where the understanding of ruminant nutrition is poor, the correct use of the protected fat is always in doubt. In most of these circumstances a considerable improvement could be made by applying, the first principle of good ruminant nutrition namely "feed the rumen first" and the technical rumen bypass products will be the next stage in development.

Therefore, the main objective of the present study was to investigate the effect of using ruminally-protected fat on some follicle and hair characteristics of goats fed halophytes to clarify the feasibility of the concept of functional foods for optimizing skin conditions. 


\section{MATERIALS AND METHODS}

Forty-two adult Shami Goats were used in a feeding trial at Ras-Sedr station belonging to Desert Research Center in Sinai as a part of a project "Adaptation to climate change in WANA marginal environments through sustainable crop and livestock diversification", which was financially supported by the International Center for Bio-saline Agriculture (ICBA), Dubai, UAE during the period from May to October 2013.

All animals were housed inside semi open shaded pens covered with corrugated asbestos sheets and drinking fresh water twice daily over all the experimental period. The experimental animals aged 4-6 years and weighted about $25 \mathrm{~kg}$ were divided into 3 groups (14 each). The first group (G1), which represented the control was fed on 60\% Berseem (Trifolium Alexandrium) hay and $40 \%$ concentrates. The second group (G2) was fed on $60 \%$ mixture of halophytes (at a percentage of 50\% Atriplex halimius and Nummularia and 50\% pearl millet) and $40 \%$ concentrates. The third group (G3) was fed on the same diet supplemented with $30 \mathrm{~g} / \mathrm{head} /$ day ruminally protected fat (Magnapac). The protected fat (calcium soaps) that was used in this research is being tested in the sheep industry and is a new option for producers. Both ingredients and chemical composition of experimental diets were presented as a percentage in dry matter in table (1).

All animals in the three groups were offered $675 \mathrm{~g} / \mathrm{head} /$ day dry matter intake, which are $405 \mathrm{~g} / \mathrm{head} /$ day hay, $405 \mathrm{~g} / \mathrm{head} /$ day mixture of halophytes and $270 \mathrm{~g} / \mathrm{head} / \mathrm{day}$ concentrated feed mixture as $100 \%$ of their maintenance requirements according to Kearl (1982).

Skin biopsy samples were obtained from the mid-side region of the animals and fixed by immersion in formol calcium (Barker, 1958) for histological and histochemical examinations. After 24 hours, tissues were processed and stained with haematoxylin and Eosin (Hx. E.) (Drury and Wallington, 1980). Histological measurements included internal and external wall follicle diameters, follicle wall thickness, fibre diameters, medulla thickness, sebaceous gland cell and nucleus diameters. The follicle wall thickness was determined by subtraction of the average of internal diameter from the average of external diameter for each follicle. Histochemical demonstration of general carbohydrates were performed by Periodic acid Schiff's (PAS) reaction (Mc-Manus and Cason, 1950), while bromophenol blue stain was used for general proteins (Chapman, 1975). Both histological and histochemical parameters were measured using Image Analyzer software (Zen, 2012, Blue edition) and device Carl-Zeiss micro-imaging Gmbh) with lenses 10/0.847 and 40/0.65. 
Table (1). Ingredients and chemical composition (\% in dry matter of experimental diets).

\begin{tabular}{lccc}
\hline \multirow{2}{*}{ Ingredients } & \multicolumn{3}{c}{ Experimental diets } \\
\cline { 2 - 4 } & $\begin{array}{c}\text { Concentrated feed } \\
\text { mixture }\end{array}$ & Hay & $\begin{array}{c}\text { Halophytes } \\
\text { mixture }\end{array}$ \\
\hline Hay & - & 60 & - \\
Mixture of halophytes & - & - & 60 \\
Yellow corn & 55 & 55 & 55 \\
Wheat bran & 15 & 15 & 15 \\
Soybean meal & 10 & 10 & 10 \\
Undecorticated cotton seed meal & 14 & 14 & 14 \\
Molasses & 3 & 3 & 3 \\
Mineral mix & 1 & 1 & 1 \\
Lime stone & 1 & 1 & 1 \\
Sodium chloride & 1 & 1 & 1 \\
Total & 100 & 100 & 100 \\
\hline Nutrients \% & & & \\
Dry matter (DM) & 91.95 & 89.61 & 90.70 \\
Organic matter (OM) & 93.61 & 88.61 & 81.96 \\
Crude protein (CP) & 14.37 & 13.44 & 11.39 \\
Crude fibre (CF) & 7.16 & 27.92 & 23.13 \\
Nitrogen free extract (NFE) & 68.97 & 44.87 & 45.31 \\
Ether extract (EE) & 3.11 & 2.38 & 2.13 \\
Ash & 6.39 & 11.39 & 18.04 \\
\hline
\end{tabular}

Data were analyzed with SAS (2004) program using general linear models (GLM) procedure for analysis of variance and using the nutritional diets as sets. Means were significantly separated using Duncan's multiple range tests.

\section{RESULTS AND DISCUSSION}

The use of lipids in ruminant's diet can bring benefits, especially due to their high energy density with low calorie increase. However, unsaturated fatty acids can affect the rumen fermentation, and a way around this fact is the use of "protected lipids", which are not fully utilized by the microorganisms in the rumen, passing through the small intestine reducing the negative effect of fat and consequently on the degradability of fibre (Muller et al., 2005).

Shami goat-skin has two follicle types, primary and secondary. The primaries are usually the largest, in the skin often three, while the secondary are the smallest size, more numerous and lie on one side of the primaries (Fig. 1). Histologically, all follicle types have the same basic structure. The wall of the hair follicle is divided into two distinct layers, the outer and inner 
root sheaths. The mean difference between the primary and secondary follicles was the presence of both sweat and sebaceous glands and erector muscle accompanying the primary follicles, while the secondary have only the sebaceous glands (Fig. 1). The primary follicles with their associated secondary follicles constitutes the hair follicle group, which is considered the unit of hair production.

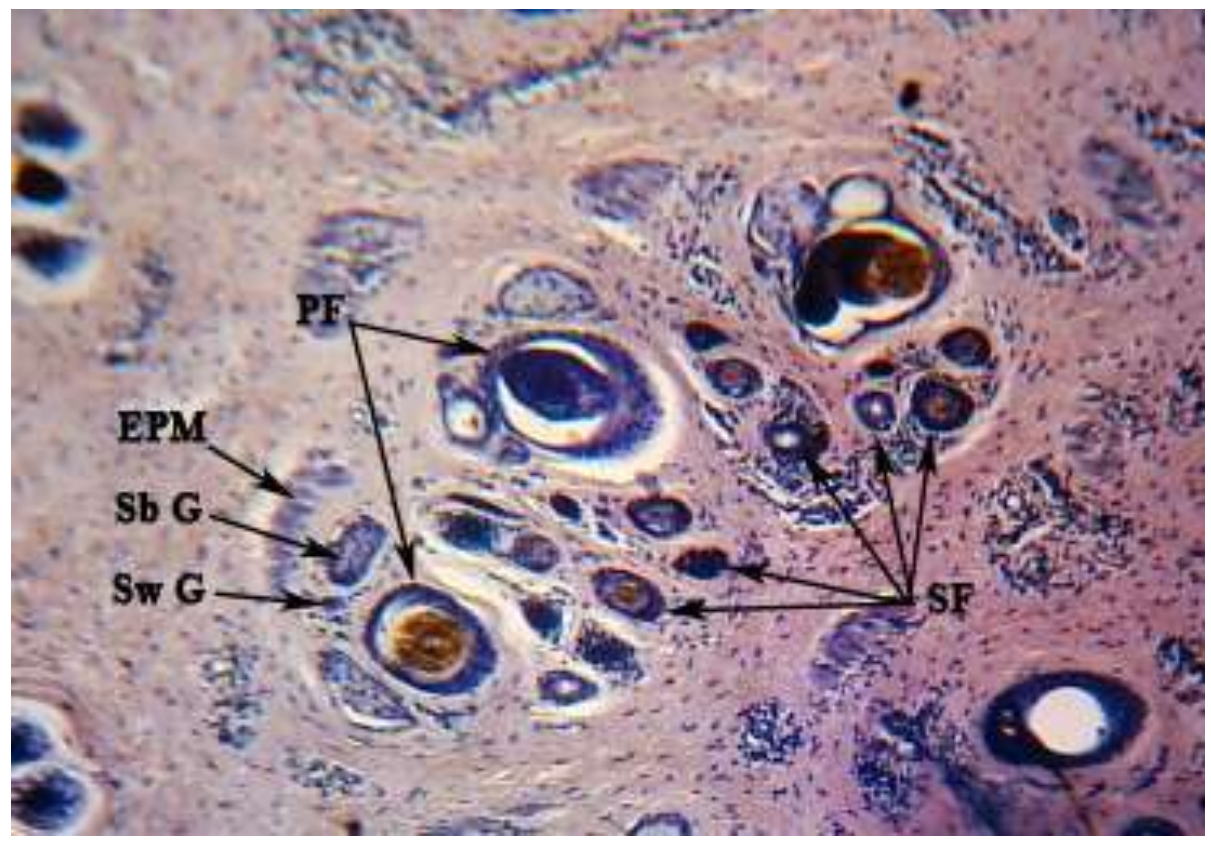

Fig. (1). Transverse section in the skin of Shami goat showing its detailed structure. EPM, erector pili muscle; PF, primary follicle; Sb G, sebaceous gland; SF, secondary follicle; Sw G, sweat gland. (Hx.E., 100).

The impact of nutrition on the hair growth of grazing goats has long been appreciated, with periods of poor pasture growth or quality reflected in a reduction in total hair growth per animal. The relationship between nutrient intake and product output reflects changes in the supply of substrates, which are essential for fibre synthesis in the hair follicle.

The amount of hair produced by Shami goats has affected by different nutritional factors depend to a large extent on the number and size of the growing follicles as well as the rate of fibre growth. The follicle dimensions recorded in table (2) reflect the follicle ability to produce fibre materials. Primary follicles are usually larger than secondary ones and the coarser fibers or guard hairs are usually grown from primary follicles. The secondaries produce the fine fibres. 
Table (2). Mean values of follicle diameters and wall thickness $(\mu \mathrm{m} \pm \mathrm{S}$.E) in Shami goats fed on different feed nutrients.

\begin{tabular}{llccc}
\hline $\begin{array}{l}\text { Follicle } \\
\text { type }\end{array}$ & Feed type & $\begin{array}{c}\text { External } \\
\text { diameter }\end{array}$ & $\begin{array}{c}\text { Internal } \\
\text { diameter }\end{array}$ & $\begin{array}{c}\text { Wall } \\
\text { thickness }\end{array}$ \\
\hline Primary & Control & $188.05 \pm 7.65^{\mathrm{a}}$ & $105.76 \pm 4.66^{\mathrm{a}}$ & $82.29 \pm 4.83^{\mathrm{a}}$ \\
follicle & Halophytes & $177.22 \pm 5.60^{\mathrm{ab}}$ & $100.54 \pm 3.41^{\mathrm{a}}$ & $76.68 \pm 3.54^{\mathrm{a}}$ \\
& Protected fats & $162.06 \pm 9.52^{\mathrm{b}}$ & $103.06 \pm 5.80^{\mathrm{a}}$ & $59.00 \pm 6.01^{\mathrm{b}}$ \\
\hline Secondary & Control & $58.94 \pm 1.47^{\mathrm{b}}$ & $18.00 \pm 0.65^{\mathrm{b}}$ & $40.94 \pm 1.15^{\mathrm{a}}$ \\
follicle & Halophytes & $65.64 \pm 1.33^{\mathrm{a}}$ & $25.30 \pm 0.59^{\mathrm{a}}$ & $40.34 \pm 1.04^{\mathrm{a}}$ \\
& Protected fats & $68.92 \pm 2.10^{\mathrm{a}}$ & $26.78 \pm 0.94^{\mathrm{a}}$ & $42.15 \pm 1.64^{\mathrm{a}}$ \\
\hline
\end{tabular}

Only values with different letters are significantly different $(P<0.05)$

A small or non-significant changes was found in the external diameter and wall thickness of the primary follicles, while the internal diameter of the same follicles showed non-significant difference among the values in different experimental groups (Table 2). The highest values of the primary follicle dimensions were detected in the control group (G1), which recorded $188.05 \pm 7.65,105.76 \pm 4.66$ and $82.29 \pm 4.83 \mu \mathrm{m}$ in the external, internal diameter and wall thickness, respectively.

In secondary follicles, table (2) illustrated that there was a significant increase in the values of the external and internal diameters of the treated groups (G2 and G3) than those of the control group (G1), which show no significant difference between the values of each other. They showed external diameter values of $65.64 \pm 1.33$ and $68.92 \pm 2.10 \mu \mathrm{m}$ versus $58.94 \pm 1.47 \mu \mathrm{m}$ in the control group and internal diameter values of $25.30 \pm 0.59$ and $26.78 \pm 0.94 \mu \mathrm{m}$ versus $18.00 \pm 0.65 \mu \mathrm{m}$ in the control group.

The results of the present study emphasized the importance of inner root sheath of the hair follicles in estimating hair follicle output and subsequently the fibre formation. Whereas, Mahgoub et al. (1974) stated that the greater thickness of the outer root sheath and large number of cell layers constituting it could be explained the greater activity and large fibres.

The results in table (2) also showed that the wall thickness of the secondary follicles was not affected significantly according to different feeding groups. The present results indicate that all follicle diameters were positively correlated with each other and with fibre diameter. Table (2) also illustrated that there were more obvious positive correlation between secondary follicles diameter and its fibre than that in the primary follicle and this was attributed to the level at which diameters were measured in accordance with (Abdou et al., 2007). Burns (1966) attributed the fluctuation in the follicle dimensions to the changes in the follicle activity during development of the wool fibres, thus the size of the follicle or its various parts may vary through its different nutritional conditions. Several studies indicated that the level of feeding and nutrients affected follicle activity and 
fibre growth (Hynd et al., 1997; Hynd and Masters, 2002 and White et al., 1994).

The decreased follicle dimensions in primary and secondary follicles of both treatment groups (G2 and G3) may be due to feeding on Atriplex and pearl millet, which affected significantly feed intake that lower the crude protein to 11.39 (Table 1) and resulted in a clear-cut responses in fibre growth to protein and only small responses associated with energy reversal of the effects noted for diets digested in the rumen as in the study of Kempton (1979). On another point of view, the use of protected fat in the diet influenced significantly consumption of all nutrients (Pinto et al., 2011). They also stated that the use of protected fat in the diet of Santa Ines lambs reduces the dry matter intake and increases the ether extract consumption.

The decrease in primary follicle dimensions in groups (G2 and G3) leads to decrease in their hair fibre diameters, which recorded 74.81 \pm 3.09 $\mu \mathrm{m}$ in group (2) and $75.77 \pm 5.26 \mu \mathrm{m}$ in group (3) compared with $89.00 \pm 4.23$ $\mu \mathrm{m}$ in group (1) as shown in table (3). The secondary fibre diameters showed the opposite trend of the primaries with no significant differences between both treatment groups (G2 and G3).

Table (3). Mean values of fibre diameters $(\mu \mathrm{m} \pm$ S.E) produced by both primary and secondary follicles in Shami goats fed on different feed nutrients.

\begin{tabular}{lcc}
\hline Feed type & Primary fibres & Secondary fibres \\
\hline Control & $89.00 \pm 4.23^{\mathrm{a}}$ & $13.06 \pm 0.57^{\mathrm{b}}$ \\
Halophytes & $74.81 \pm 3.09^{\mathrm{b}}$ & $18.53 \pm 0.51^{\mathrm{a}}$ \\
Protected fat & $75.77 \pm 5.26^{\mathrm{b}}$ & $19.10 \pm 0.81^{\mathrm{a}}$ \\
\hline
\end{tabular}

Only values with different letters are significantly different $(P<0.05)$

It is well known that feeding animals with halophytes has significant effect on their feed intake and subsequently on follicle activity and fibre diameter. This may be due to the increasing neutral detergent fibre content in this diet, which limits its consumption by animals (Givens et al., 2000) and due to anti-nutritional components of these forages (Aslani, 2004). The noninfluence of the protected fat on fibre growth is probably due to the fact that part of the fat source is inactive in the rumen and probably what was fermented in this compartment was not enough to negatively influence the food degradation so it could affect animal performance (Pinto et al., 2011).

Kemp fibres or guard hairs produced from the primary follicles constitute the outer coat of the Shami goats. The major factors influencing the proportion of medullated fibres are genetics and age (Tiffany-Castiglioni, 1986 and Lupton et al., 1991). In the present work, table (4) confirmed that there were non-significant changes in the values of medulla thickness of Shami goat fibres in related to feed type in groups G2 and G3. This result is in harmony with those obtained on primary fibre diameter of the different 
studied groups. This subject has been reviewed by Tiffany-Castiglioni (1986) and Lupton et al. (1991), who concluded that the proportions of medullated and kemp fibres are not markedly affected by nutrient supply.

Table (4). Mean values $(\mu \mathrm{m} \pm$ S.E) of medulla thickness in fibres of Shami goats fed on different feed nutrients.

\begin{tabular}{cc}
\hline Feed type & Medulla thickness \\
\hline Control & $48.27 \pm 3.45^{\mathrm{a}}$ \\
Halophytes & $40.90 \pm 5.35^{\mathrm{a}}$ \\
Protected fat & $43.03 \pm 3.79^{\mathrm{a}}$ \\
\hline
\end{tabular}

Only values with different letters are significantly different $(P<0.05)$.

Histochemically, active hair follicles were always rich in carbohydrates (Matter et al., 1998). The outer root sheath of both primary and secondary active hair follicles was laden with carbohydrates (Fig. 2). The carbohydrates are considered the sign of follicle activity according to the assumption of Montagna (1956) that the carbohydrates in the outer root sheath is the source of energy for protein synthesis during fibre growth. In the present study, the presence of carbohydrates in both primary and secondary follicles showed an increased follicle activity in the animals of group (3), which have fed additive (protected fat) (Table 5), followed by the other two experimental groups.

Table (5). Mean optical density (O.D.) values of different histochemical reactions of the hair follicles in the skin of Shami goats fed on different feed nutrients.

\begin{tabular}{|c|c|c|c|c|c|}
\hline \multirow{2}{*}{$\begin{array}{c}\text { Histochemical } \\
\text { parameters }\end{array}$} & \multirow[t]{2}{*}{ Feed type } & \multicolumn{2}{|c|}{ Primary follicle } & \multicolumn{2}{|c|}{ Secondary follicle } \\
\hline & & $\begin{array}{c}\text { Outer root } \\
\text { sheath }\end{array}$ & $\begin{array}{c}\text { Inner root } \\
\text { sheath }\end{array}$ & $\begin{array}{c}\text { Outer root } \\
\text { sheath }\end{array}$ & $\begin{array}{c}\text { Inner root } \\
\text { sheath }\end{array}$ \\
\hline \multirow[t]{3}{*}{ Carbohydrates } & Control & $0.35 \pm 0.012^{b}$ & $0.34 \pm 0.011^{\mathrm{a}}$ & $0.49 \pm 0.021^{\mathrm{a}}$ & $0.33 \pm 0.017^{b}$ \\
\hline & Halophytes & $0.34 \pm 0.015^{\mathrm{b}}$ & $0.28 \pm 0.015^{\mathrm{b}}$ & $0.37 \pm 0.020^{\mathrm{b}}$ & $0.27 \pm 0.016^{\mathrm{c}}$ \\
\hline & $\begin{array}{c}\text { Protected } \\
\text { fat }\end{array}$ & $0.42 \pm 0.012^{\mathrm{a}}$ & $0.35 \pm 0.011^{\mathrm{a}}$ & $0.48 \pm 0.014^{\mathrm{a}}$ & $0.41 \pm 0.011^{\mathrm{a}}$ \\
\hline \multirow[t]{3}{*}{ proteins } & Control & $0.36 \pm 0.038^{\mathrm{c}}$ & $0.35 \pm 0.036^{\mathrm{c}}$ & $0.58 \pm 0.026^{\mathrm{b}}$ & $0.52 \pm 0.025^{\mathrm{ab}}$ \\
\hline & Halophytes & $0.57 \pm 0.026^{\mathrm{b}}$ & $0.54 \pm 0.025^{\mathrm{b}}$ & $0.54 \pm 0.034^{b}$ & $0.46 \pm 0.033^{\mathrm{b}}$ \\
\hline & $\begin{array}{c}\text { Protected } \\
\text { fat }\end{array}$ & $0.74 \pm 0.019^{\mathrm{a}}$ & $0.64 \pm 0.098^{\mathrm{a}}$ & $0.66 \pm 0.016^{\mathrm{a}}$ & $0.56 \pm 0.016^{\mathrm{a}}$ \\
\hline
\end{tabular}

Only values with different letters are significantly different $(P<0.05)$. 


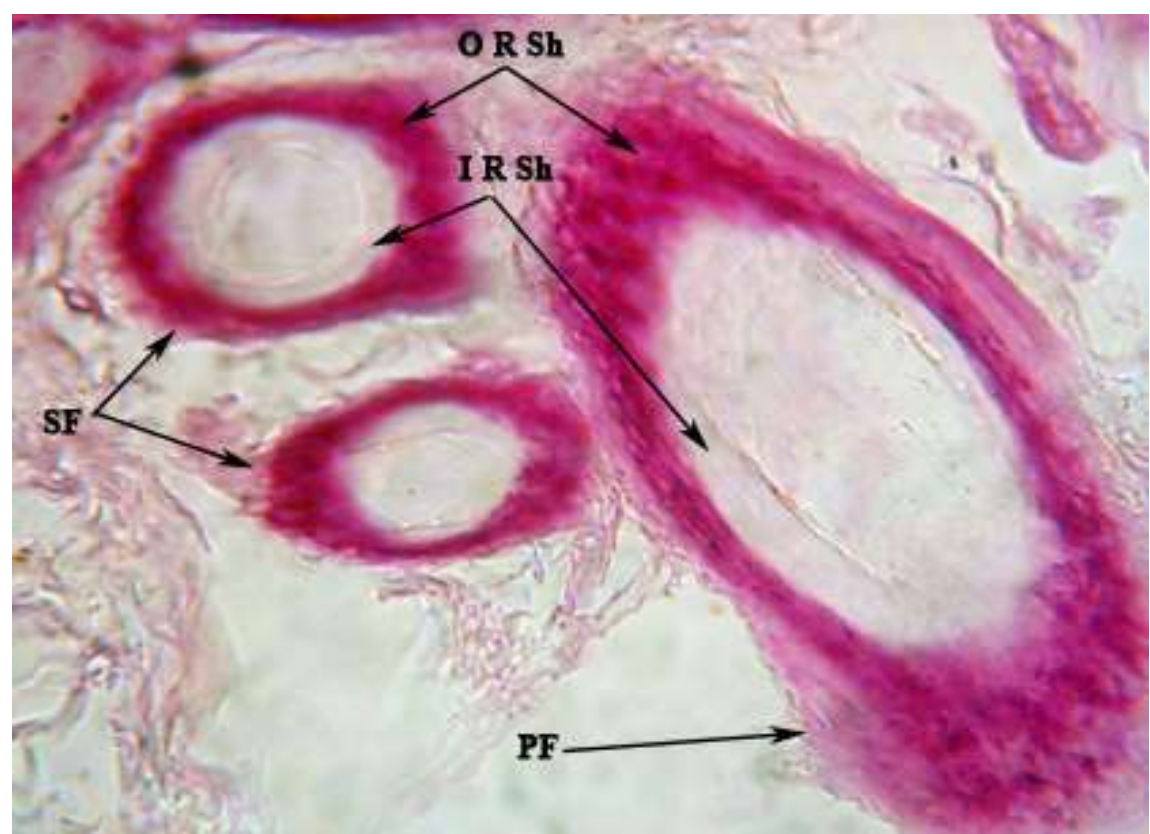

Fig. (2). Transverse section in a primary and secondary hair follicles of Shami goat skin showing the presence of general carbohydrates in the inner (IRSh) and outer (ORSh) root sheaths (PAS, x 400).

From the follicle viewpoint, glucose is readily available from glycogen stored in the outer root sheath. Whether carbohydrate metabolism is important, because it determines the total quantity of energy substrates required for fibre growth. Chapman and Ward (1979) concluded that the pentose phosphate pathway is active in follicles to supply the high level of pentose required for the synthesis of nucleic acid for cell division and protein synthesis in the follicle. The changes in the carbohydrate content in the present study may be due to the presence of pearl millet, which is considered as a source of energy as well as the supplementation of the feed mixture with protected fat, that reduces the dry matter intake and increases the ether extract consumption (Pinto et al., 2011).

On another point of view, the activity of the follicles represented by the growth rate of fibres depends on 1) the number and size of cells in the proliferative zone of the follicle bulb and the proportion of newly formed cells that migrate from this zone, 2) the rate of division of bulb cells, 3) the proportion of migrating cells that enter the fibre and 4) the increase in size of cells forming the fibres (Black and Ries, 1979). In (1994) Reis and Sahlu stated that most of these events are influenced by the nutrient supply to the follicles. In addition, Parmar et al. (1988) ensured that the higher protein content in active wool follicle sheaths are associated with an increased protein synthesis during the cellular proliferation. 
The distribution of the general proteins in the different sheaths of both primary and secondary follicles is demonstrated in table (5) and fig. (3). The highest value of the protein content was recorded in the follicles of animals in group (3) the diet of which enclosed with protected fat (Table 5). A significant increase in the general protein contents was found in both outer and inner root sheaths of the primary follicles $(0.74 \pm 0.019$ and $0.64 \pm 0.098)$ and also in the secondary follicle sheaths $(0.66 \pm 0.016$ and $0.56 \pm 0.016)$, respectively. These results could be explained by the fact that the protected fats represent as a good source of energy. The inclusion of protected fat and protected protein in the diets of feedlot cattle as shown by Scott and Ashes (1993) increased metabolizable energy and non-degradable protein.

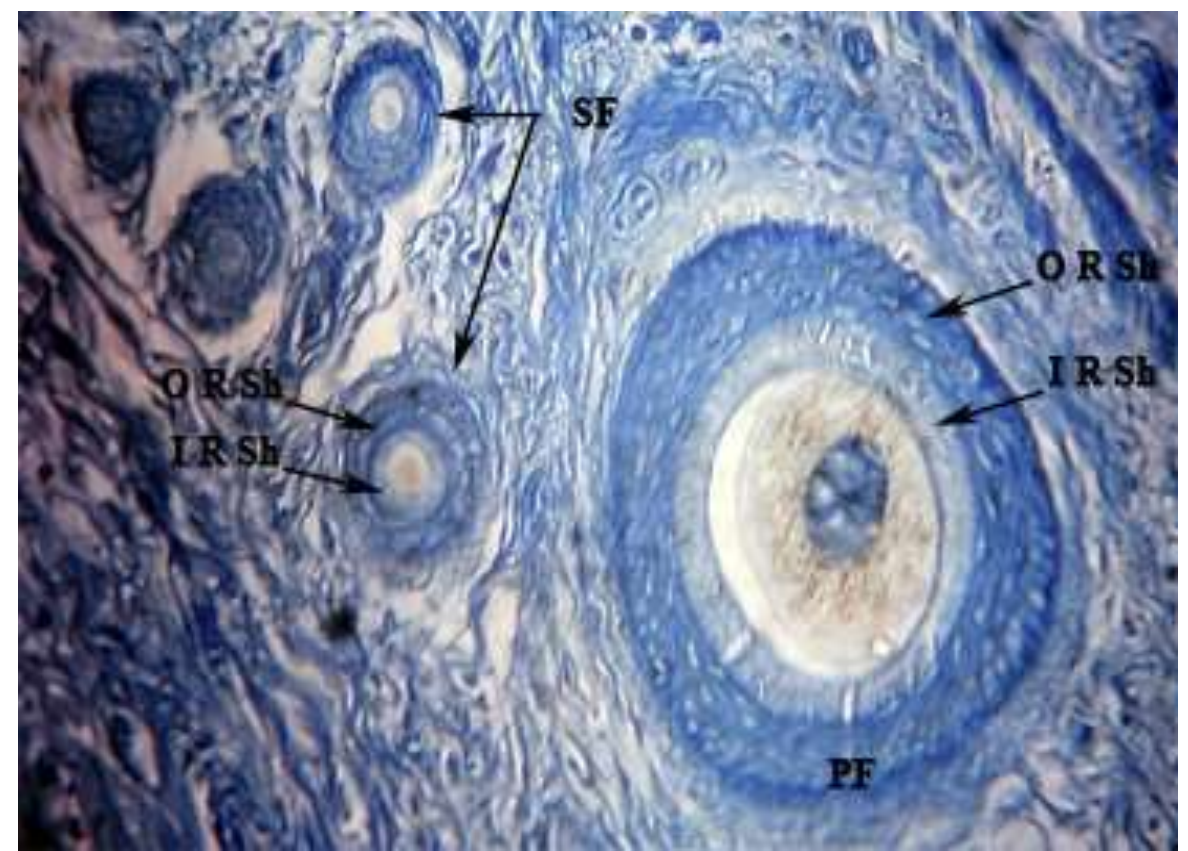

Fig. (3). Transverse section in the skin of Shami goat stained with bromophenol blue showing the general protein content in the different hair follicles (x.400).

The similarity in protein values between the different experimental groups (Table 6) could be referred to the foundation of crude proteins in quantities near to each other in the three experimental diets (Table 1) and this may explain the same trend in the follicle dimensions as illustrated in table (2). The increment of the source of energy and proteins can affect follicle activity and fibre production as demonstrated by Reis et al. (1988). 
Table (6). Mean diameter values $(\mu \mathrm{m} \pm \mathrm{S}$.E) of the sebaceous gland cells and nuclei in Shami goats fed on different feed nutrients.

\begin{tabular}{lccc}
\hline Follicle type & Feed type & Cell diameter & $\begin{array}{c}\text { Nucleus } \\
\text { diameter }\end{array}$ \\
\hline $\begin{array}{l}\text { Primary } \\
\text { follicle }\end{array}$ & $\begin{array}{c}\text { Control } \\
\text { Halophytes } \\
\text { Protected } \\
\text { fats }\end{array}$ & $13.24 \pm 0.27^{\mathrm{a}}$ & $5.65 \pm 0.13^{\mathrm{a}}$ \\
& $14.11 \pm 0.66^{\mathrm{a}}$ & $6.04 \pm 0.13^{\mathrm{b}}$ \\
\hline $\begin{array}{l}\text { Secondary } \\
\text { follicle }\end{array}$ & $\begin{array}{c}\text { Control } \\
\text { Halophytes } \\
\text { Protected } \\
\text { fats }\end{array}$ & $9.06 \pm 0.30^{\mathrm{a}}$ \\
\hline
\end{tabular}

Only values with different letters are significantly different $(P<0.05)$.

In all groups of the experimental animals, primary follicles were associated with big sebaceous gland volume in comparison with that of the secondary follicles (Fig. 4). The cell and nucleus diameters of the sebaceous glands followed the same pattern (Table 6). The third group (G3), which have protected fat in their diets showed the highest mean values of the sebaceous gland cell and nucleus diameters in the primary follicles recorded $14.11 \pm 0.62$ and $6.06 \pm 0.30 \mu \mathrm{m}$ with non-significant difference than those of the control group (G1) $(13.24 \pm 0.27$ and $5.65 \pm 0.13 \mu \mathrm{m})$, respectively. The second group (G2) fed halophytes recorded a significant decrease in their measurements (Table 6). Similarly, the sebaceous gland cell diameter of the secondary follicles showed the same trend of those of primary follicles (Table 6), while the nucleus diameter possessed no significant difference in their mean values in relation to different feed types in all groups of animals.

There is an evidence indicating that dietary factors alter sebaceous gland output. Llewellyn (1967) demonstrated that sebum production can be increased by the consumption of dietary fat or carbohydrate. Variation in carbohydrates can also affect sebum composition (Mac Donald, 1964 and 1967). Dietary habit, supplying substrates for the sebaceous lipid synthesis, can be involved in the sebum production mechanism (Rasmussen, 1977).

Generally, the results in the present study indicated that increasing values of fats treated halophytes may elevate the negative effects of poor quality fibrous feed on hair production by Shami goats. This was in accordance with the findings of Sanz Sampelayo et al. (2002), who noticed that when the ruminant diet is supplemented with fats, a greater efficiency is achieved in the use of metabolizable energy for animal production.

The obtained results in this experiment could indicate that small or non-significant differences in the hair follicle dimensions or activities between tested and control groups were found at both feeding halophytes mixture and after supplementation with protected fat periods. Such grasses could be used successively and safely as good quality fodders to solve the 
problems of feed shortage and to increase the economical value of the marginal saline resources in Egypt. This research has highlighted several areas in which more information is needed regarding to effects of nutrition and other environmental factors on the quantity and quality of the hair fibres produced by Shami goats. In particular, the importance of specific nutrients should be investigated. To maximize financial returns, it is important to know the relative responses of both length and diameters of fibres to changes in nutrient supply.

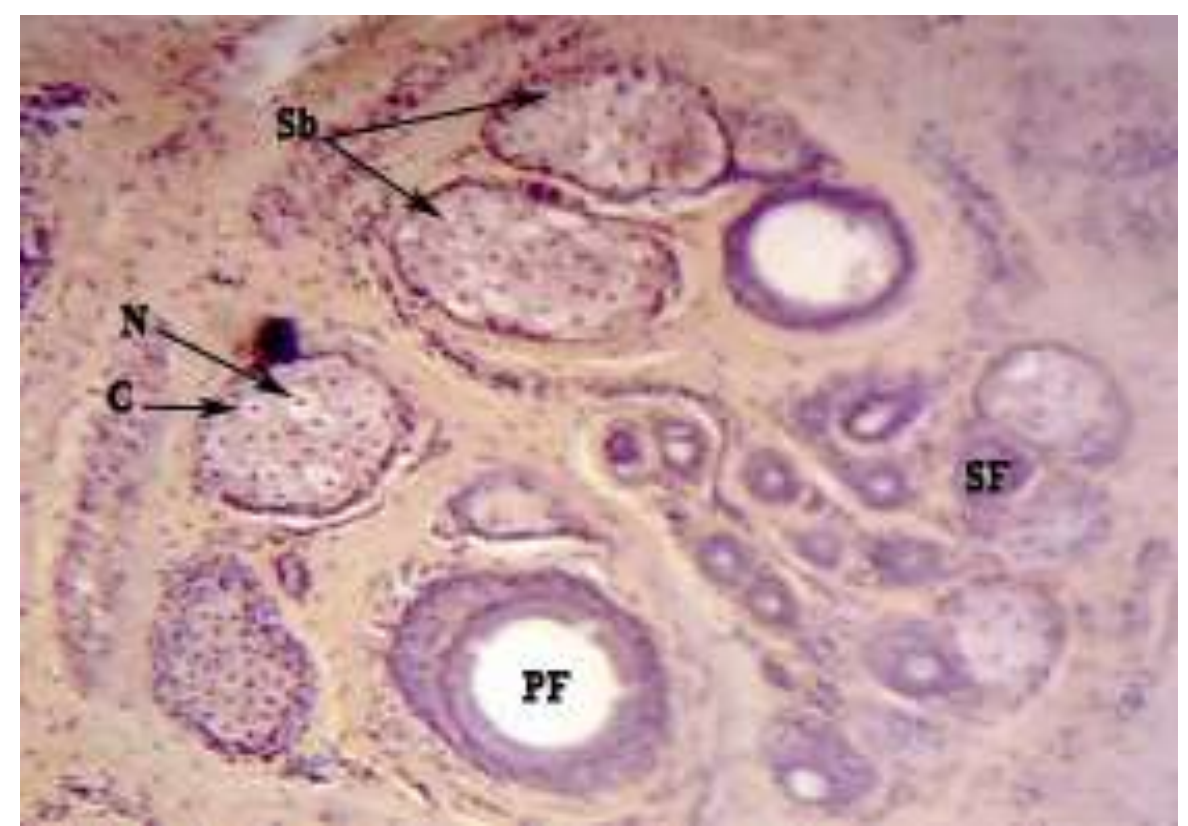

Fig. (4). Transverse section through the primary (PF) and secondary (SF) hair follicles and associated sebaceous glands $(\mathrm{Sb})$ in the skin of Shami goat. C, cell; N, nucleus. (Hx. E., x100).

\section{ACKNOWLEDGMENT}

This research was conducted as a part of the project "Adaptation to climate change in WANA marginal environments through sustainable crop and livestock diversification", which was financially supported by the International Center for Biosaline Agriculture (ICBA), Dubai, UAE. The authors' thanks and appreciation is extended to Prof. Dr. Hassan M. El-Shaer Professor of Animal Nutrition, Desert Research Center for his assistance in this experiment. 


\section{REFERENCES}

Abdou, A.S., H.H. Swelim, N.A. El-Sayed and N.S. Badawy (2007). Brief skin structure and some coat characteristics of sheep breeds in Halayeb, Shalateen and Abou Ramad triangle in two seasons. Egyptian J. Desert Res., 57 (2): 403-428.

Aboul-Nasr, H.M. (1998). Vetch (Vicia monantha) straw as a basal diet with Acacia or Atriplex shrubs for sheep under arid condition of Egypt. First International Conference on "Animal Production and Health in Semi Arid Areas", 1-3 September, Cairo, Egypt.

Aslani, M.R. (2004). Iranian's toxic plants and toxicity in animals. Ferdousi University Press. Mashhad, Iran (in Persian), p. 77-78.

Barker, J.R. (1958). In "Principles of Biological Technique". London, Methuen, New York, John Wiley, Bancroft. J.D.

Black, J.L. and P.J. Reis (1979). In "The Physiological and Environmental Limitations to Wool Growth". (Eds. J.L. Black and P.J. Res.) University of New England Publ. Unit, Armidale, N.S.W.

Boelsma, E., H.F. Hendriks and L. Roza (2001). Nutritional skin care: health effects of micronutrients and fatty acids. Am. J. Clin. Nutr., 73: 853-64.

Burns, M. (1966). Merino birthcoat fibre types and their follicular origin. J. Agric. Sci. Camb., 66: 155-173.

Chapman, D.M. (1975). Dichromation of bromophenol blue with an improvement in the mercuric bromophenol blue technique for protein. Stain Technology, 50: 25-30.

Chapman, R.E. and Ward, K.A. (1979). In "Histological and Biochemical Features of the Wool Fibre and Follicle". Black, J.L. and Reis, P.J. (eds.). Physiological and Environmental Limitations to Wool Growth. University of New England, Armidal, Australia, p. 193208.

Craig, A.M., E.G. Pearson, C. Meyer and J.A. Schmitz (1991). Serum level enzyme and histopathologic changes in calves with chronic and chronic-delayed Senecio jacobaea toxicosis. Am. J. Vet. Res., 52 (12): 1969-1978.

Drury, R.A.B. and E.A. Wallington (1980). In "Carleton's Histological Technique". 4th. Ed. Oxford University Press, Oxford, New York, Toronto.

El-Shaer, H.M. (1995). Potential use of cultivated range plants as animal feed in the Mediterranean coastal zone of Egypt. Proc. The $8^{\text {th }}$ Meeting of FAO working group on Mediterranean pastures and fodder crops. "Sylvopastoral System, Environmental, Agricultural and Economic Sustainability" Avignon, France, 29 May-2 June. 
Girgis, W.A. (1994). Project of "Development of range resources and fodders in Sinai" (Final report). Desert Research Center and Academy of Scientific Research and Technology, Egypt.

Givens, D.I., E. Owen, R.F.E. Axford and H.M. Omed (2000). Forage evaluation ruminant nutrition. CABI Pub., $480 \mathrm{pp}$.

Hynd, P.I. and D.G. Masters (2002). In "Nutrition and Wool Growth". Sheep Nutrition. CAB. Int., 400 p.

Hynd, P.I., A. Hughes, C.R. Earl and N.M. Penno (1997). Seasonal changes in the morphology and activity of wool follicles in fine wool and strong wool Merino strains at different stocking rates in southern Australia-Aus. J. Agriv. Res., 49: 1089-1097.

Kearl, L.C. (1982). Nutrient requirements of ruminants in developing countries. Utah Agric. Exp. Sta. Utah State Univ., Iogam, USA.

Kempton, T.J. (1979). In "Protein and Energy Ratio of Absorbed Nutrients in Relation to Wool Growth". (Black, J.I. and P.J. Reis eds.). Physiological and Environmental Limitation to Wool Growth. University of New England, Armidale, Australia, p. 209-222.

Llewellyn, A. (1967). Variations in the composition of skin surface lipid associated with dietary carbohydrates. Proc. Nutr. Soc., 26: 11.

Lupton, C.J., F.A. Pfeiffer and N.E. Blakeman (1991). Medullation in mohair. Small Ruminant Research, 5 (4): 357-365.

Mac Donald, L. (1964). Changes in fatty acid composition of sebum associated with high carbohydrate diets. Nature, 203: 1067-1068.

Mac Donald, L. (1967). Dietary carbohydrates and skin lipids. Br. J. Dermatol., 79: 119-121.

Mahgoub, A.E.S., M.F.A. Fahmy and Y.S. Ghanem (1974). A histological study of the skin of some breeds of sheep.1. Layers of the skin. The Egyptian Veterinary Medical Journal, Faculty of Veterinary Medicine, Cairo University, XX11 (22.1991) 51: 303-307.

Matter, F.E., M.M. El-Ganaieny, N.A. Shawky and A.S. Abdou (1998). Seasonal variations and wool follicles of Barki sheep raised under desert conditions in Egypt. Desert Institute Bulletin, Egypt, 48 (2): 385-407.

Mc-Manus, J.P.A. and J.E. Cason (1950). Carbohydrate histochemistry studied by acetylation techniques periodic acid method. J. Exp. Med., 91: 651.

Montagna, W. (1956). In "The Structure and Function of Skin". Academic Press, New York.

Muller, M., I.N. Prado and L.A.R. Junior (2005). Differences fonts de lipideos sobre o desempenhoe caracteristicas da carcaca de novilhas de corte confinadas. Animal Science, 27 (1): 131-137.

Egyptian J. Desert Res., 65, No. 2, 327-342 (2015) 
Parmar, M.L., R.D. Sinha, G. Parasad and J. Prasad (1988). Histochemical studies on hair follicles and sebaceous and sweat gland in goat. Indian Journal of Animal Sciences, 58 (7): 789-791.

Pinto, A.P.P., I.F.F. Garcia, I. Leopoldino Junior, J.R.O. Perez, N.G. Alves and I.G. Pereira (2011). Performance and carcass characteristics of lambs fed diets with fat and vitamin E.R. Bras. Zootec., 40 (12): 2911-2921.

Rasmussen, J. (1977). Diet and acne. Int. J. Dermatol., 16: 488-491.

Reis, P.J. and T. Sahlu (1994). The nutritional control of the growth and properties of mohair and wool fibres. J. Anim. Sci., 72: 18991907.

Reis, P.T., D.A. Tunks and S.G. Munes (1988). Relative importance of amino acids and energy for wool growth. Proceeding of the Nutrition Society of Australia, 13: 122.

Sanz Sampelayo, M.R., L. Perez, J.J. Martin Alonso, F. Gil Extremera and J. Boza (2002). Effect of concentrates with different contents of protected fat rich in PUFAs on the performance of lactating Granadina goats 1. Feed intake, nutrient digestibility, $\mathrm{N}$ and energy utilization for milk production. Small Rumin. Res., 43: 133-9.

SAS (2004). Statiscal Analysis System Institute, SAS User's Guide Statistics, SAS Institute Inc., Cary, NC.

Scott, T.W. and J.R. Ashes (1993). Dietary lipids for ruminants: protection, utilization and effects on remodelling of skeletal muscle phospholipids. Australian Journal of Agricultural Research, 44 (3): 495-508.

Tiffany-Castiglioni, E. (1986). Review: Genetics and management of kemp in mohair. Texas Agric. Exp. Sta., PR 4403, Texas A \& M.

White, C.L., G.B. Martin, P.I. Hynd and R.E. Chapman (1994). The effect of zinc deficiency on wool growth and skin and wool follicle histology of male Merino lambs. British J. Nut., 71: 425-435. 
تأثير إستخدام الدهون المحمية على جلا وشعر عنزات الماعز الشـامي المغذاه

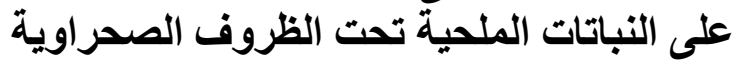

عائشة سيد عبده'"، سامية عبد المجيد هيكل'، نجلاء سالم بدوي' ، وائل أحمد رمضان'

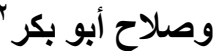

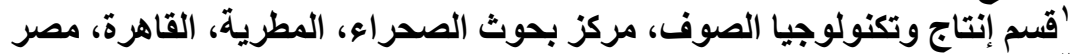

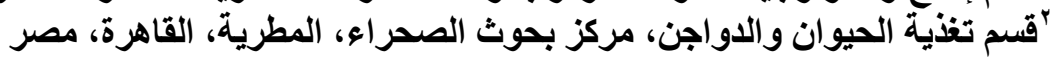

نم دراسة نأثير التغذية بالنباتات الملحية المختلطة وغير المختلطة بالدهون المحمية على ونى

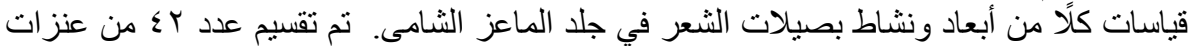

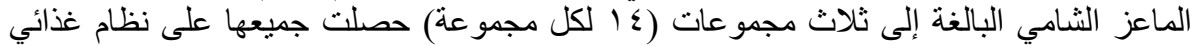

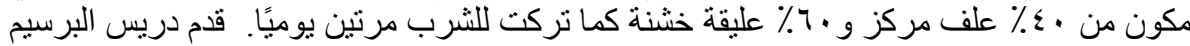

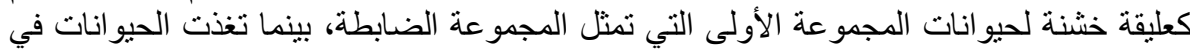

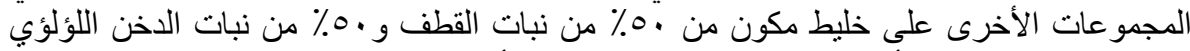

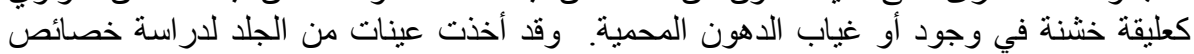

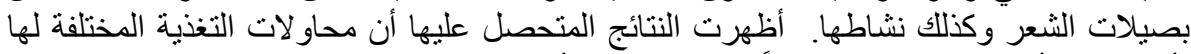

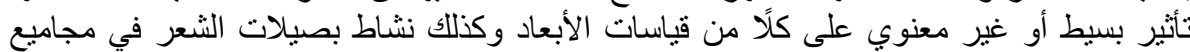

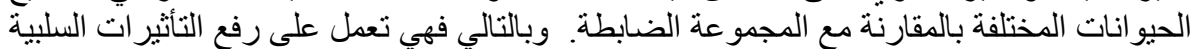

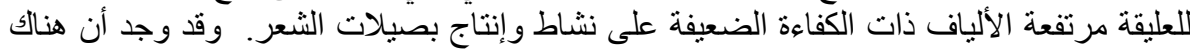

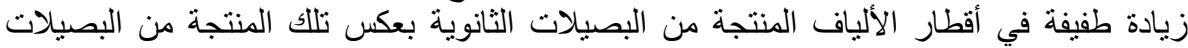

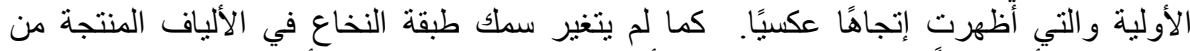

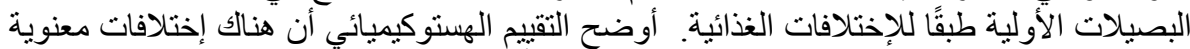

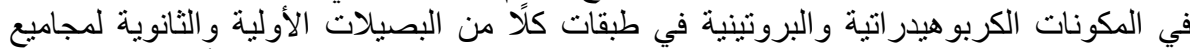

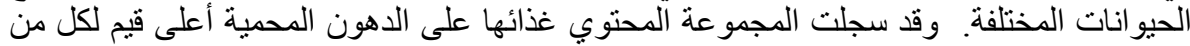

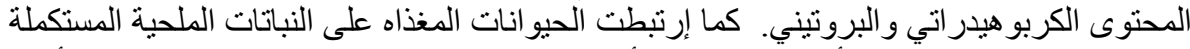

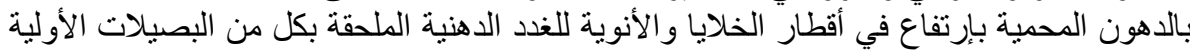

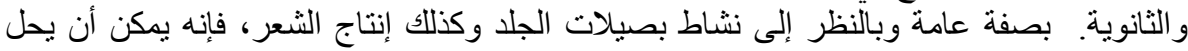

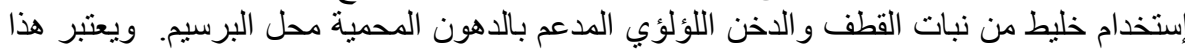
مصدر غذائي و اعد في سيناء و المناطق حديثة الإستصلاح ذات الستات الظروف البيئية المشابهة.

Egyptian J. Desert Res., 65, No. 2, 327-342 (2015) 